v. $10, n .4$

Vitória-ES, Out.-Dez. 2013

p. 65 - $90 \quad$ ISSN 1808-2386 DOI: http://dx.doi.org/10.15728/bbr.2013.10.4.3

\title{
The Role of economic variables and credit portfolio attributes for estimating discretionary loan loss provisions in Brazilian banks
}

\author{
José Alves Dantas $\dot{\zeta}^{\dot{1}}$ \\ University of Brasília \\ Otávio Ribeiro de Medeiros ${ }^{\Omega}$ \\ University of Brasília \\ Paulo Roberto Barbosa Lustosa ${ }^{¥}$ \\ University of Brasília
}

\begin{abstract}
The study assesses whether incorporating macroeconomic variables and attributes of the loan portfolio improves the specification of models designed to identify management discretion in making loan loss provisions by banks, considering the standards issued by regulatory agencies. The empirical tests confirm the consistency of the proposed model based on the expected signs of the explanatory variable's parameters and their statistical significance. These results were confronted with those of other models found in the literature by comparing the models' adjusted $\mathrm{R}^{2} \mathrm{~s}$, by applying Vuong's (1989) model selection test, by using an F test for nested models, and by analyzing the persistence of the non-discretionary components of loan loss provisions, which shows that the incorporation of macroeconomic variables and attributes of the loan portfolio improves the empirical investigation of discretion practiced by banks.
\end{abstract}

Keywords: Loan loss provision; discretion; banks; earnings management; Brazil.

Received 03/15/2013; revised 08/20/2013; accepted 09/27/2013; published 12/13/2013.

* Corresponding Authors:

\footnotetext{
${ }^{\dagger}$. $\mathrm{PhD}$ in Accounting from the University of Brasília

Affiliation: Professor at University of

Brasília

Address: Quadra 105, Lote 8, Águas

Claras, Brasília - DF - Brazil

E-mail: josealvesdantas@unb.br

Telephone: (61) 8406.9524
}

\author{
${ }^{\Omega} \mathrm{PhD}$ in Economics from the University of \\ Southampton \\ Affiliation: Professor at University of Brasília \\ Address: SQN 205 Bloco C Apto 401, Asa \\ Norte, Brasília - DF - Brazil \\ E-mail: otavio@unb.br \\ Telephone: (61)9978-9503
}

\footnotetext{
${ }^{¥}$ Phd in Accounting from the University of São Paulo Affiliation: Professor at University of Brasília Address: SQN 110, Bloco G, Apto. 103 - Asa Norte - Brasília - DF - Brasil

E-mail: lustosa@unb.br

Telephone: (61) 9237-6180
} 


\section{INTRODUCTION}

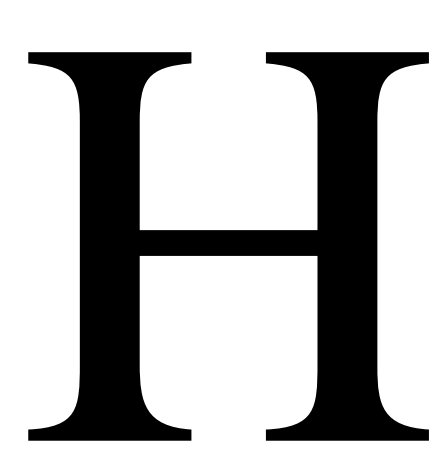

aving in mind concerns expressed by Dechow, Sloan and Sweeney (1995), McNichols (2000) and Dechow, Richardson and Tuna (2003) that the effectiveness of studies on earnings management depends on the models' capability of capturing discretionary earnings management when they actually occur, the present study aims to assess whether the incorporation of control variables representing the current macroeconomic situation and the attributes of the loan portfolio, such as types of credit operations, geographical location of debtors, degree of concentration of the portfolio and maturities of ongoing loans, are capable of improving the specification of models designed to identify management's discretion in loan loss provisions (LLP) by banks.

The justification for this is that according to regulatory agencies such as the International Accounting Standards Board (IASB, 2011), the Federal Financial Institutions Examination Council (FFIEC, 2001) and Brazil's National Monetary Councili (CMN, 1999), aspects such as the types of assets, industry sector and geographical localization of debtors and economic conditions should be taken into account by banks in the process of determining their LLP, but the models used for the estimation of non-discretionary LLP (NDLLP) are primarily based on accounting variables. In general, they are based on variables representing volumes of nonperforming loans in loan portfolios, written-off loans and loan loss allowance used as regressors explaining the NDLLP. Although some recent studies such as Kanagaretnam, Krishnan and Lobo (2009, 2010) incorporate control variables in models designed to identify the non-discretionary portion of LLP, these models generally lack some important aspects.

This study is based on the assumption that one of the requirements for a solid financial system is transparency, represented by information that adequately discloses banks' existing assets, financial situation, and earnings, in addition to other relevant aspects such as organizational structure, internal controls, and risk management as highlighted by the Basle Committee on Banking Supervision (BCBS, 1998). Considering that such transparency requirements are provided chiefly by the banks' financial statements, management earnings practices can represent a serious problem to the dissemination of the effective financial situation of these entities. In line with this understanding, Cornett, McNutt and Theranian (2006) point out that accounting choices, manipulation of financial information and earnings management is particularly critical in financial systems in view of the impacts that problems 
in banking institutions can cause on the economy. Cheng, Warfield, and Ye (2011) emphasize that the effects of the financial crisis of 2008 have increased the importance of investigating the practice of earnings management in the banking industry, considering its role in ensuring the smooth functioning of the economy.

In order to accomplish this aim and select the best model explaining the true datagenerating process, the estimation results of the proposed model are compared with other models found in the literature, using the following procedures: (i) comparison of the models' adjusted $\mathrm{R}^{2}$ s, (ii) application of Vuong's (1989) model selection test, (iii) application of the F test for comparison of nested models ((Greene, 2002), and (iv) analysis of persistence of the discretionary and non-discretionary components of LLP, using the test proposed by Dechow, Richardson and Tuna (2003). With the purpose of comparing the empirical results, all models are estimated using the same sample and data. The data were obtained from the Quarterly Financial Information reports of commercial, multiple and savings banks operating in the Brazilian banking market, from the $1^{\text {st }}$ quarter 2001 to the $3^{\text {rd }}$ quarter 2012 , which are available on the webpage of the Central Bank of Brazil (BCB).

The results confirm the consistency of our proposed model with respect to the expected signs of the regressors' coefficients and their statistical significance. When compared with other two-stage models found in the literature, we find that our model presents the secondbest adjusted $R^{2}$ statistic among the ten competitors examined. With respect to Vuong's (1989) model selection test, our proposed model is not surpassed by any other, being more accurate than six competitors and as accurate as the remaining three. With respect to the three nested models, the nested-models F test (Greene, 2002) showed that the proposed model has a better explanatory power. It was also noticed that the proposed model stands out among those showing the greatest degree of persistence of the non-discretionary component and the greatest transience of the discretionary component of LLP, as expected, which provides additional evidence of the model's robustness.

The paper contributes to the literature by demonstrating that including variables representing the current economic situation and certain attributes of the loan portfolio improves the specification of models designed to estimate the LLP disclosed by banks. Specifically, the introduction of the Gross Domestic Product (GDP) growth, the types of credit operations, the geographical location of debtors, the degree of concentration of the loan portfolio and the maturities of ongoing credit operations improve the identification of the management's discretion in determining the LLP. Our results confirm that Brazilian banks 
use the guidelines issued by regulatory authorities such as the IASB, FFIEC and CMN when determining the LLP.

Considering that the regulations issued by CMN for the computation of LLP in the Brazilian banking system constitute a hybrid model of loss provisions, having the features of both expected and incurred losses models as discussed in Section 2.2, the empirical evidence obtained in this study might be a reference to future studies in different regulatory environments.

In addition to this introduction, the paper provides a discussion about earnings management in banking (Section 2), presents the proposition of a model for the identification of the non-discretionary portion of the LLP by Brazilian banks (Section 3), describes the empirical tests comparing the competing models (Section 4), presents the empirical results and analysis (Section 5), and concludes (Section 6).

\section{EARNINGS MANAGEMENT IN BANKING}

The banking industry has proven to be a critical environment for studies on earnings management, which expose serious concern with respect to the quality of the accounting information in banks, especially regarding the possibility that they might conceal risks endangering their financial robustness. Among the reasons mentioned by authors such as Cornett, Mcnutt and Theranian (2006), Goulart (2007) and Cheng, Warfield and Ye (2011), we highlight the criticality of the banking system in ensuring the smooth functioning of the economy, the systemic consequences of eventual problems in banks for the economy as a whole, the need for creating an environment of trust and credibility of banking institutions and the requirements of transparency implicit to the banking system and required by regulators.

An important aspect to be considered here is market discipline. According to Stephanou (2010), market discipline is the mechanism by which market participants monitor and discipline excessive risk-taking behavior by banks. Market discipline is related to the institutional framework - information, incentives and control - used to reduce moral hazard and information asymmetry that are frequently present in banking. In spite of the existing market discipline, evidence exists concerning the unethical and opportunistic behavior often demonstrated by banks. For example, Marcondes (2008) finds empirically that accounting manipulation, obtained by means of discretionary accruals, has permitted banks to pay lower interest rates to depositors than the risk ratios would imply. 
In summary, research on earnings management performed by banks, in addition to clarifying the need for reducing information asymmetry among economic agents, involves the search for full, fair and neutral financial disclosure, which contributes to the confidence, solidity and proper functioning of the banking system.

\subsection{AGGREGATE ACCRUALS VS. SPECIFIC ACCRUALS}

According to Healy and Wahlen (1999), analysis of accruals is one of the most important methods used in empirical studies on earnings management. It considers two possible dimensions: aggregate accruals and specific accruals. The latter, focused on the analysis of specific accounts or in a particular industry, provides the opportunity for a more consistent and suitable modelling of the problem (Cheng, Warfield and Ye, 2011), being considered by Healy and Wahlen (1999) and McNichols (2000) as having the greatest potential for advancement in research.

This is particularly relevant considering the debate about the difficulty of detecting and measuring earnings management (Dechow, Sloan and Sweeney, 1995) as well as about the limitations of econometric models in capturing management's discretion in accrual accounting (Jones, Krishnan and Melendrez, 2008). However, the choice of a more limited scope - the banking industry - associated with the possibility of analysing the behavior of a specific account - the LLP -, provides the opportunity for better model specifications, mitigating the risk of omission or errors in choosing the relevant explanatory variables. According to Kanagaretnam, Krishnan and Lobo (2010), the use of specific accruals in an industry such as banking provides a more appropriate segregation of discretionary and nondiscretionary components and allows for other cross-sectional differences in accruals, increasing the reliability of the empirical analyses.

\subsection{THE USE OF LLP FOR EARNINGS MANAGEMENT IN BANKS}

The discretion concerning LLP as well as its effects on the robustness of the banking system, has been a subject of lively debate among professionals, academics and regulators. For example, the Federal Reserve Release of November 24, 1998, in which U.S. regulatory agencies claim that, although the process of determining the level of LLP is necessarily derived from managers' decisions under uncertainty, this should not be used to manipulate earnings or deceive investors, depositors, regulators or other parties involved.

Not by chance is the area that has recorded the largest number of studies on earnings management in banking, which is explained by Kanagaretnam, Lobo and Mathieu (2003) and Alali and Jaggi (2010) on the basis that LLP represents the largest accruals in banks, creating 
the conditions for potential accounting manipulations. Gray and Clarke (2004) reinforce this understanding by saying that LLP in banks is considered the primary vehicle for managing earnings, bearing in mind its inherent subjectivity.

Generally, the practice of earnings management in banking using LLP stems from the fact that managers often make elusive judgments about the subject. Within the framework of Brazil's National Financial System, for example, the parameters for the constitution of LLP are defined by CMN's Norm 2.682 of December 21, 1999, which determines that credit operations should be classified within an increasing order of risk, with a proportion of loss provision for each risk level, according to a scale ranging from $0 \%$ for risk level AA up to $100 \%$ for risk level H. Subjectivity comes from the criteria used by the management to define this rating. Since the norm establishes that, after a certain time the loan should be reclassified or written off as appropriate, the adopted procedure can be defined as mixed, based on both the expected model and incurred model regulatory concepts, which diverges from the standards recommended by IASB.

\subsection{MODELS USED FOR THE IDENTIFICATION OF DISCRETIONARY LLP IN BANKS}

Two types of procedures can be adopted when modelling specific accruals for the identification of earnings management practices by means of regression analysis. The first one uses one-stage models in which the association between the behavior of the accruals under examination and the variable(s) of interest, generally an accounting earnings measure, is assessed in order to identify, for example, its possible use in income smoothing. The second uses two-stage models. In the latter case, a model with variables explaining the nondiscretionary behavior of the account in question is estimated in the first stage. In this type of model, the estimated residuals represent the discretionary portion, which is used as the dependent variable in the second stage, in order to assess its relationship with regressors explaining the management's opportunist action.

Studies investigating the use of LLP in earnings management in banks provide examples of the two types of procedure and the choice of procedure depending on the researchers' aims in each particular study. Kim and Kross (1998), Ahmed, Takeda and Thomas (1999), Lobo and Yang (2003), Shrieves and Dahl (2003), Goulart (2007) and Alali and Jaggi (2010), for example, use one-stage models in their investigations. Beaver and Engel (1996), Kanagaretnam, Lobo and Mathieu (2003, 2004), Zendersky (2005), Marcondes (2008), Kanagaretnam, Krishnan and Lobo (2009, 2010), Kanagaretnam, Lim and Lobo 
(2010) and Cheng, Warfield and Ye (2011), among others, adopt the two-stage models to tackle their research goals.

Considering that the purpose of this study is to compare the results obtained by means of different models to assess whether the incorporation of variables representing the macroeconomic situation and characteristics of the loan portfolio improves model specification for identification of discretion in LLP, we specifically evaluate two-stage models, with the proviso that one-stage models use, in most cases, control variables that are compatible with two-stage models.

In general, two-stage models used for the estimation of non-discretionary LLP include as regressors accounts representing the volumes of loan portfolios, nonperforming loans, written-off loans, and loan loss allowance. A synthesis of the two-stage models previously mentioned and the explanatory variables they use is shown in Table 1.

Table 1: Two-stage models explaining the non-discretionary portion of LLP in banks and their variables

\begin{tabular}{|c|c|c|c|c|c|c|c|c|c|c|c|c|}
\hline Model & $L O A N$ & $\triangle L O A N$ & $\begin{array}{l}N P L \\
(-1)\end{array}$ & $N P L$ & $\triangle N P L$ & $\begin{array}{l}\triangle N P L \\
(+1)\end{array}$ & $\angle C O$ & $\begin{array}{l}\text { LLA } \\
(-1)\end{array}$ & $I N T$ & TYP & $P E R$ & Other \\
\hline (A) & & $\mathbf{X}$ & & & $\mathbf{X}$ & $\mathbf{X}$ & $\mathbf{X}$ & & & & & \\
\hline (B) & & $\mathbf{X}$ & $\mathbf{X}$ & & $\mathbf{X}$ & & & & & & & \\
\hline (C) & & $\mathbf{X}$ & $\mathbf{X}$ & & $\mathbf{X}$ & & & & & & & \\
\hline (D) & & $\mathbf{X}$ & $\mathbf{X}$ & & $\mathbf{X}$ & & $\mathbf{X}$ & $\mathbf{X}$ & & & & \\
\hline (E) & $\mathbf{X}$ & $\mathbf{X}$ & $\mathbf{X}$ & & $\mathbf{X}$ & & $\mathbf{X}$ & $\mathbf{X}$ & $\mathbf{X}$ & & $\mathbf{X}$ & \\
\hline (F) & & $\mathbf{X}$ & $\mathbf{X}$ & & $\mathbf{X}$ & & $\mathbf{X}$ & $\mathbf{X}$ & & & $\mathbf{X}$ & $\mathbf{X}$ \\
\hline (G) & $\mathbf{X}$ & $\mathbf{X}$ & $\mathbf{X}$ & & $\mathbf{X}$ & & $\mathbf{X}$ & $\mathbf{X}$ & & $\mathbf{X}$ & $\mathbf{X}$ & \\
\hline$(\mathrm{H})$ & $\mathbf{X}$ & $\mathbf{X}$ & & $\mathbf{X}$ & & & $\mathbf{X}$ & $\mathbf{X}$ & & $\mathbf{X}$ & $\mathbf{X}$ & $\mathbf{X}$ \\
\hline (I) & & $\mathbf{X}$ & & & $\mathbf{X}$ & $\mathbf{X}$ & $\mathbf{X}$ & & & & & \\
\hline
\end{tabular}

Models: (A) Beaver and Engel (1996); (B) Kanagaretnam, Lobo and Mathieu (2003); (C) Kanagaretnam, Lobo and Mathieu (2004); (D) Zendersky (2005); (E) Marcondes (2008); (F) Kanagaretnam, Krishnan and Lobo (2009); (G) Kanagaretnam, Krishnan and Lobo (2010); (H) Kanagaretnam, Lim and Lobo (2010); (I) Cheng, Warfield and Ye (2011).

Variables: $L O A N$ is the total value of loans; NPL is the volume of nonperforming loans; $\triangle N P L$ is the change in the volume of nonperforming loans; $\boldsymbol{L C} \boldsymbol{O}$ is the net volume of written-off loans; $\boldsymbol{L} \boldsymbol{L A}$ is the loan loss allowance; $\boldsymbol{I N T}$ is the implicit interest rate charged by banks in their loan portfolio; $\boldsymbol{T Y} \boldsymbol{P}$ is a vector of control variables representing the type of loan included in the portfolio; $\boldsymbol{P E R}$ is a dummy variable controlling for time periods; $\Delta$ is the first-difference operator; $(-1)$ indicates that the variable is lagged by one period; $(+1)$ means that the variable is led by one period.

The incorporation of variables related to the loan portfolio ( $L O A N$ and $\triangle L O A N$ ) follows the assumption that the greater the volume of loans, the larger the provision to be made to 
offset eventual losses. It is worth mentioning, however, that Marcondes (2008), Kanagaretnam, Krishnan and Lobo (2010) and Kanagaretnam, Lim and Lobo (2010) used both measures simultaneously when they actually overlap, since the change in loans is already included in the loan current balance.

The variables related to the volume of nonperforming loans (NPL and $\triangle N P L)$ have a clear relationship with the level of $L L P$, since they represent the risk of losses with the bank's receivables. Most models use the lagged balance of these accounts and their current change as regressors. Only Kanagaretnam, Lim and Lobo (2010) used the current nonperforming loans at time $t$ as regressor, but they do not include changes. Beaver and Engel (1996) and Cheng, Warfield and Ye (2011) chose to incorporate the led $\triangle N P L$ among the regressors, based on the assumption that $L L P$ at time $t$ anticipates the operations that will default in time $t+1$.

The value of written-off loans ( $L C O$ ) was incorporated as an explanatory variable of $L L P$ in seven of the nine models analyzed under the argument that it represents the materialization of loss itself, and therefore there must be a relevant and significant relationship between these variables. With respect to the loan loss allowance ( $L L A)$, its inclusion as an explanatory variable stems from the assumption that the expectations of losses already reserved is an indicator of the quality (or lack thereof) of the loan portfolio, which should entail further adjustments in $L L P$.

Controlling for the effects of the characteristics of loans composing LLP in each period has been considered only in more recent studies, such as Kanagaretnam, Krishnan and Lobo (2010) and Kanagaretnam, Lim and Lobo (2010). This is because different types of loans and financing $(T Y P)$ operations have different impacts on LLP requirements. On the other hand, controlling for changing time periods $(P E R)$, which has been contemplated in four more recent studies, is aimed at capturing changes in the economic scenario over time.

Finally, a variable representing the implicit interest rate charged in credit operations (INT) was added as another explanatory variable as suggested by Marcondes (2008) under the argument that portfolios with higher interest rates are those possessing greater risk and, consequently, requiring greater LLP.

\section{THE PROPOSED MODEL}

In this study, the proposed model for the identification of the discretionary portion of LLP is based on previous studies, reviewed in Section 2.3, with the addition of explanatory variables embodying normative recommendations and economic factors considered in the 
constitution of LLP by banks.

For this purpose, guidelines issued by CMN and IASB are the main references. CMN's Resolution 2.682/1999 establishes that, when computing the LLP, banks should consider, among other factors, the industrial sector to which corporate debtors belong and aspects relating to the loans such as the nature and purpose of the loan, its amount, and the characteristics of collateral. Besides, IAS 39, when referring to the execution of impairment tests of loans and receivables, determines that, in addition to analyzing the relevant loans individually, loans must be grouped together according to their risk characteristics and must take into account the type of asset, industry sector, geographical location, type of collateral, payment delay and other relevant factors.

These references are also compatible with the guidelines issued by the FFIEC (2001). Aimed specifically at the U.S. banking and leasing industries, it recommends that, when estimating LLP, all available information, including environmental factors as well as the industry sector, geographical location, economic conditions and political aspects, must be contemplated.

Considering these principles, a model for estimating the non-discretionary and the discretionary components (the residuals) within the LLP disclosed by banks was specified in Equation (3.1).

$$
\begin{aligned}
L L P_{i, t}= & \beta_{0}+\beta_{i}+\beta_{1} \Delta L O A N_{i, t}+\beta_{2} N P L_{i, t-1}+\beta_{3} \Delta N P L_{i, t}+\beta_{4} L C O_{i, t}+\beta_{5} L L A_{i, t-1}+\beta_{6} I N T_{i, t} \\
& +\beta_{7} G D P_{t}+\psi_{1}<T Y P_{i, t}>+\psi_{2}<G E O_{i, t}>+\psi_{3}<M A T_{i, t}>+\psi_{4}<C N C_{i, t}>+\varepsilon_{i t}
\end{aligned}
$$

where:

$L L P_{i, t}:$ provision for loan losses of bank $i$ in period $t$

$\triangle L O A N_{i, t}$ : change in the value of loans from period $t-1$ to $t$ of bank $i$;

$N P L_{i, t-1}: \quad$ nonperforming loans in period $t-1$ of bank $i$;

$\triangle N P L_{i, t}$ : change in the value of nonperforming loans from period $t-1$ to $t$ of bank $i$;

$L C O_{i, t}: \quad$ net loan write-offs of bank $i$ in period $t$;

$L L A_{i, t-1}: \quad$ loan loss allowance of bank $i$ in period t-1;

$I N T_{i, t}$ : average implicit interest rate of the loan portfolio of bank $i$ in period $t$, corresponding to the ratio between revenues from credit operations and the portfolio's average 
balance;

$G D P_{t}:$ rate of change in Gross Domestic Product in period $t$;

$\left\langle T Y P_{i, t}\right\rangle$ : vector of control variables representing the proportions of loans of bank $i$ in period $t$ distributed into public sector $(P U B)$, private sector $(P R V)$ and non-residents (NRES);

$<G E O_{i, t}>$ : vector of control variables representing the proportions of loans of bank $i$ in period $t$ located in the following geographic regions: Southeast $(S E)$, other regions of Brazil $(O R B)$ and overseas $(E X T)$;

$\left\langle M A T_{i, t}>\right.$ : vector of control variables representing the proportions of loans of bank $i$ in period $t$ distributed according to the maturity of loans: up to 5 years (UP5Y), and exceeding 5 years $(E X 5 Y)$; and

$\left\langle C N C_{i, t}\right\rangle$ : vector of control variables representing the proportions of loans of bank $i$ in period $t$ distributed in the one hundred largest customers $(U P 1 H)$, and to other customers $(E X 1 H)$.

Adopting a procedure that is usual in quantitative accounting studies such as Kanagaretnam, Lim and Lobo (2010), variables $L L P, \triangle L O A N, N P L, \triangle N P L, L C O$ and $L L A$ were normalized by total assets as of the beginning of the period..

With respect to the independent variables, we expect positive relationships between $L L P$ and the change in loans, nonperforming loans, change in nonperforming loans, net written-off loans and lagged loan loss allowance. These are the signs of these relationships usually observed in previous studies, as discussed in Section 2.3.

The expected relationship between $L L P$ and $\triangle L O A N$ can be explained by the logical and deductive assumption that the larger the amount of change in a bank's loan portfolio, the larger the provision to cover eventual losses must be. With respect to nonperforming loans, the assumption adopted is that there exists a direct relationship between the level of $L L P$ and lagged $N P L$ and its change, $\triangle N P L$, since these represent the best indicators of the loan portfolio quality. The expected positive relationship between $L L P$ and $L C O$ is supported by the reasoning that the loan write-offs represent, by definition, the materialization of losses, and hence, the larger the value of $L C O$, the larger the value of $L L P$. The relationship of $L L A$ with $L L P$ is based on the expectation that the recognition of accumulated potential losses up to the preceding period is an indication of the loss of quality of the portfolio quality, which will require new adjustments in $L L P$ in the current period. $\triangle L O A N, N P L, \triangle N P L, L C O$ and 
$L L A$ are variables usually included in models attempting to explain $L L P$ in banks. Additional discussion on these variables can be found in Beaver and Engel (1996), Kanagaretnam, Lobo and Mathieu (2003, 2004), Zendersky (2005), Marcondes (2008), Kanagaretnam, Krishnan and Lobo (2009, 2010), Kanagaretnam, Lim and Lobo (2010), and Cheng, Warfield and Ye (2011), as synthesized in Table 1.

Following Marcondes (2008), we incorporated the implicit interest rate of the loan portfolio (INT) as an explanatory variable with an expected positive sign, considering that portfolios with higher interest rates carry a greater implied risk, which should be reflected in an increased $L L P$ to offset potential losses. This expected relationship is supported by the assumption that the higher the risk associated to the client and to the specific loan, the higher the interest rate charged by the financial institution and, consequently, the higher the provision for eventual losses.

The rate of change of economic activity $(G D P)$ was included in the model following FFIEC (2001) guidance that the constitution of LLP should consider, among other factors, the current economic situation. This procedure is also supported by Gray and Clarke (2004), who propose a method for calculating the LLP in commercial banks that takes into account the prevailing economic conditions. As an example of the potential effects of GDP change on the constitution of LLP, we can mention the impact of the global financial crisis of 2008. In traditional models that incorporate explanatory accounting variables only, the effects of the crisis on the perspective of loan losses would not be captured in due time. A negative relationship is expected between $L L P$ and the rate of change in GDP, on the assumption that defaults should be more frequent during times of economic stagnation and less relevant in times of economic growth. Although the studies cited in Section 2.3 do not specifically incorporate a variable portraying the economic situation, we point out that controlling for time periods as in Marcondes (2008), Kanagaretnam, Krishnan and Lobo (2009, 2010) and Kanagaretnam, Lim and Lobo (2010) is also a way of controlling the effects of changes in the economic situation over time.

Additionally, consistent with the guidelines for the constitution of $L L P$ established in Resolution CMN 2.682/99, IAS 39 and FFIEC (2001), we incorporate vectors of variables intended to control for some of the attributes of the loans portfolio: the type of loan (TYP), the debtors' geographic location (GEO), the loan portfolio's degree of concentration and the loan maturity $(M A T)$. This procedure also finds support in the method suggested by Gray and Clarke (2004) for calculating $L L P$. 
With respect to the type of loan, Kanagaretnam, Krishnan and Lobo (2010) and Kanagaretnam, Lim and Lobo (2010) use equivalent variables in their specifications. In the present study, we controlled for the proportion of loans to the public and private sectors, and to non-residents. The rationale for this is that these different groups of borrowers have different levels of credit risk, which should reflect, in consequence, in different levels of LLP recognition. With respect to the geographic location of debtors, the reasoning is that in a large country such as Brazil, different regions might be subject to specific economic conditions, which could affect differently the capacity of payment of borrowers from different locations. With the purpose of controlling for this fact, we take into account the proportion of the portfolio corresponding to loans granted to (1) borrowers from the Southeast region, the country's richest, most populated and having the most dynamic economy, (2) from other regions, and (3) from abroad. Controlling for the maturity of the loan portfolio is necessary because of the relationship between maturity and risk. If maturity affects the level of risk of a loan, by logic, it must affect the loan loss provision. With the purpose of capturing this effect, we include as variables the proportions of loans with maturities up to five years and those with maturities over five years. Finally, we also control in the proposed model for the degree of concentration of the portfolio. This is justified by the assumption that the exposure to credit risk is a function of a higher or lower concentration of loans relative to the borrowers. Accordingly, the proportions of the loan portfolio granted to the one hundred largest clients and to others are included in the model.

Finally, regarding the risk of endogeneity between LLP and loans attributes in Equation 3.1, we should not disregard such functional relationship in the model, as loans are the base upon which non-discretionary LLP is formed. Besides, in Brazil, this relationship is still more important, since CMN's Resolution 2.682/1999 rules that banks must measure LLP as a function of both loans and nonperforming loans. Furthermore, we emphasize that this is a procedure widely used in the literature on the subject, such as Beaver and Engel (1996), Kanagaretnam, Lobo and Mathieu (2003, 2004), Kanagaretnam, Krishnan and Lobo (2009, 2010), Kanagaretnam, Lim and Lobo (2010) e Cheng, Warfield and Ye (2011).

\section{METHODS}

In this section, we show how the proposed model is submitted to tests in order to verify whether it improves the specification of the management's discretion in the calculation of the LLP in banking. 


\subsection{DATA}

The data utilized in the empirical testing were taken from the Quarterly Financial Information reports of 224 commercial banks, multiple banks and savings banks belonging to the Brazilian financial system during the period between the $1^{\text {st }}$ quarter 2001 and the $3^{\text {rd }}$ quarter 2012, available on BCB's website. Because of some missing data, the total number of pooled bank x period observations is 6,901 , forming an unbalanced panel.

\subsection{MODEL TESTING}

Using the above-mentioned data, we estimated the parameters associated with the explanatory variables of models A to I described in Table 1, together with the parameters of the explanatory variables specific of the model proposed in this study, as described in Equation (3.1). As in previous studies cited in Section 2.3, the LLP reported by each bank in each period has two components: a non-discretionary portion (NDLLP) and a discretionary portion $(D L L P)$, with the latter corresponding to the residuals of the first regression estimated, as shown in Equation (4.1):

$$
L L P_{i, t}=N D L L P_{i, t}+D L L P_{i, t}
$$

It should be noted that models A to I in Table 1 cannot be regarded as literal replications of those of their originating studies due to the following adjustments: (i) we do not include "other variables," considered in models F and H of Kanagaretnam, Krishnan and Lobo (2009) and Kanagaretnam, Lim and Lobo (2010), respectively, which represent incentives for the earnings management practice, such as the level of risk-adjusted capitalization, and (ii) we standardize the criteria for the normalization of variables, while in the original studies, different normalization procedures of the accounting variables were adopted, based on net worth or the balance of the loan portfolio.

\subsection{VALIDATION OF THE PROPOSED MODEL AND TESTS FOR THE COMPARISON OF MODELS}

The validation of the proposed model is initially made by checking if the regression parameters are consistent with expectations. Then, tests were performed to compare these results with those of models $A$ to $I$, involving comparison of the models' adjusted $R^{2} s$, application of Vuong's (1989) model selection test, the use of a test for nested models, and analysis of persistence of the discretionary and non-discretionary components of LLP.

a) Comparison of adjusted $R^{2} s$ 
Following Dechow, Richardson and Tuna (2003), the first stage to test the adequacy of the proposed model consists of comparing its adjusted $\mathrm{R}^{2}$, a measure of goodness of fit that penalizes the loss of degrees of freedom according to the number of regressors in the equation, with those of the competing models existing in the literature.

\section{b) Vuong's (1989) model selection test}

The second procedure to identify the model that best estimates the behavior of LLP in banks is the application of the model selection test developed by Vuong (1989), which has been also used, among others, by Dechow (1994) and Subramanyam (1996). In short, it provides a likelihood ratio statistic to test the null hypothesis that two competing models are equally efficient in explaining the true data generation process against the alternative hypothesis that one of the models is more accurate. In practice, the statistical test, hereinafter called $z$-vuong, is performed by means of a series $\left(m_{i t}\right)$, corresponding to the likelihood ratio $(L R)$, constructed from the regression residuals $\left(\varepsilon_{i t}\right)$ and the residuals sum of squares $(R S S)$ derived from the estimation of the two competing models ( $\mathrm{X}$ and $\mathrm{Y}$, for example) as in Equation (4.2):

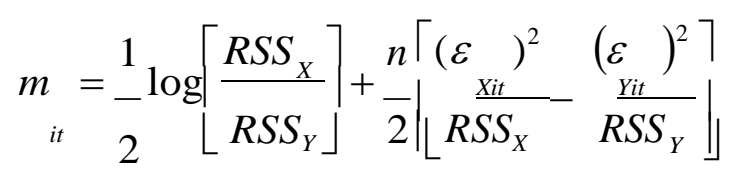

After obtaining the $m$ series, a linear regression of $m$ on a constant $c$ is estimated; i.e.:

$$
m_{i t}=c+\varepsilon_{i t}
$$

where $\varepsilon_{i t}$ is an error term $\sim \operatorname{IID~N}\left(0, \sigma^{2}\right)$.

The $z$-vuong statistic is obtained as shown in the following equation:

$$
z=t *\left[\frac{n-1}{n}\right\rfloor
$$

where $t$ is the $t$ ratio associated with the constant (c) estimated from Equation (4.3), and $n$ is the number of observations. A positive $z$-vuong statistic means that the residuals produced by model $\mathrm{X}$ are larger than those produced by model $\mathrm{Y}$. If this statistic is significant, considering the critical level selected, one can conclude that model $\mathrm{Y}$ is the most appropriate. If the statistic is negative and statistically relevant, the choice falls on model X. 


\section{c) Test of nested models}

Since Vuong's (1989) test is only applicable to non-nested models, we additionally performed the $\mathrm{F}$ test for nested models (Greene, 2002). The test compares the residual sum of squares of the reduced model $\left(R S S_{R}\right)$ with that of the complete model $\left(R S S_{C}\right)$, under the null that the parameters of the additional variables included in the complete model are equal to zero, which is tested according to the following F statistic:

$$
F=\frac{\left(R S S_{R}-R S S_{C}\right) / p}{R S S_{C} /[n-(k+p+1)]} \sim F\left(v_{1}, v\right)
$$

where: $\boldsymbol{n}$ is the number of observations, $k$ is the number of parameters in the reduced model, $\boldsymbol{p}$ is the number of extra parameters added to form the complete model, $v_{1}=\mathrm{p}$, and $v_{2}=$ $\mathrm{k}+\mathrm{p}+1$.

If the null is rejected, it means that at least one of the parameters of the variables added to the reduced model is different from zero, which improves the regression.

\section{d) Analysis of persistence of the discretionary and non-discretionary components}

In the third stage we assess the persistence of the discretionary and non-discretionary components of LLP. Analogous to Dechow, Richardson and Tuna (2003), who assessed the persistence of the earnings components, we evaluate whether the discretionary component of $L L P$ is more transient than its non-discretionary counterpart. The assessment of persistence of the discretionary and non-discretionary components of $L L P$ is based on Equation (4.6):

$$
L L P_{i, t+1}=\alpha+\beta_{n} L L P_{i, t}+\varepsilon_{i, t+1}
$$

Breaking $L L P_{i, t}$ down into its discretionary and non-discretionary components, we get:

$$
L L P_{i, t+1}=\alpha+\beta_{1} N D L L P_{i, t}+\beta_{2} D L L P_{i, t}+\varepsilon_{i, t+1}
$$

Accordingly, we estimate model (4.6) using the discretionary component DLLP (residuals) and the non-discretionary components NDLLP. DLLP is the series of residuals estimated from models (3.1), A, B, C, D, E, G, H and I, respectively. NDLLP is the difference between $L L P$ and DLLP. Considering the implicit transient nature of the discretionary component, we expect that it has a smaller coefficient than that of the non-discretionary component. On the other hand, it is clear that the greater the coefficient of the nondiscretionary component, the higher its persistence, thus indicating a better model fitting. 


\section{EMPIRICAL RESULTS}

Unit root tests were not performed, given that we are dealing here with a micro panel, where $\mathrm{N}$ is large and $\mathrm{T}$ is small, so that nonstationarity is not a reason for concern (Baltagi, 2008).

We reinforced the robustness of the results by estimating the models by cross-section SUR fixed-effects, which provides robust coefficients and standard errors, even when heteroscedasticity and contemporaneous correlation in the errors across equations hold. It should be mentioned that the alternative of random effects estimation was discarded, since it relies on the assumption that the errors are random extractions of a much larger population, which is not the case in the present study, where the sample comprises all banks operating in the Brazilian market; i.e., the entire population.

\subsection{RESULTS OBTAINED WITH THE PROPOSED MODEL}

Table 2 summarizes the results of the regression performed on Equation (3.1).

Table 2: Estimation results for Equation (3.1) with fixed cross-section effects, p-values in parentheses

\begin{tabular}{|c|c|c|c|c|c|c|}
\hline \multicolumn{7}{|c|}{$\begin{aligned} L L P_{i, t} & =\beta_{0}+\beta_{i}+\beta_{1} \Delta L O A N_{i, t}+\beta_{2} N P L_{i, t-1}+\beta_{3} \Delta N P L_{i, t}+\beta_{4} L C O_{i, t}+\beta_{5} L L A_{i, t-1}+\beta_{6} I N T_{i, t} \\
& +\beta_{7} G D P_{t}+\psi_{1}<T Y P_{i, t}>+\psi_{2}<G E O_{i, t}>+\psi_{3}<M A T_{i, t}>+\psi_{4}<C N C_{i, t}>+\varepsilon_{i t}\end{aligned}$} \\
\hline$C$ & $\triangle L O A N$ & $N P L(-1)$ & $\triangle N P L$ & $\angle C O$ & $L L A(-1)$ & $I N T$ \\
\hline 0.0079 & 0.0112 & 0.1482 & 0.1275 & 0.0506 & 0.0050 & 0.0037 \\
\hline$(0.012)$ & $(0.000)$ & $(0.000)$ & $(0.000)$ & $(0,004)$ & $(0,305)$ & $(0.079)$ \\
\hline$* *$ & $* * *$ & $* * *$ & $* * *$ & $* * *$ & & * \\
\hline$G D P$ & $P R V$ & NRES & $S E$ & $E X T$ & EX5Y & $U P 1 H$ \\
\hline-0.0186 & -0.006 & -0.0048 & -0.0018 & -0.0036 & -0.0081 & 0.0033 \\
\hline$(0.001)$ & $(0.044)$ & $(0.127)$ & $(0.095)$ & $(0.008)$ & $(0.041)$ & $(0.000)$ \\
\hline$* * *$ & $* *$ & & $*$ & $* * *$ & $* *$ & $* * *$ \\
\hline \multicolumn{7}{|c|}{$2^{\text {nd }}$ quarter $/ 2001$ to $3^{\text {rd }}$ quarter $/ 2012$} \\
\hline Observations: & \multicolumn{2}{|c|}{6,686} & $R^{2}:$ & 0,4902 & F Statistic: & 29,1266 \\
\hline Banks: & \multicolumn{2}{|c|}{208} & $\mathrm{~d} R^{2}:$ & 0,4733 & DW Statistic: & 1,7573 \\
\hline
\end{tabular}

Where $\boldsymbol{L L P}$ is the loan loss provisions; $\boldsymbol{A L O A N}$ is the change in the value of loans; $\boldsymbol{N P L}$ the value of nonperforming loans; $\boldsymbol{A N P L}$ the change in the value of nonperforming loans; $\boldsymbol{L C O}$ the net loan write-offs; $\boldsymbol{L L A}$ is the loan loss allowance; INT is the of the loan portfolio's implicit interest rate; $\boldsymbol{G D P}$ is the rate of change of the Gross Domestic Product; $\langle\boldsymbol{T Y P}\rangle$ is a vector of variables representing the proportion of the loans portfolio distributed into public sector $(\boldsymbol{P U B})$, private sector $(\boldsymbol{P R} \boldsymbol{V})$, and non-residents $(\boldsymbol{N R \boldsymbol { E } S})$; $\langle\boldsymbol{G E \boldsymbol { O }}\rangle$ is a vector of variables representing the proportion of loans distributed in the geographic regions - Southeast $(\boldsymbol{S E})$, other regions of Brazil $(\boldsymbol{O R B})$, and overseas $(\boldsymbol{E X T})$; $\langle\boldsymbol{M A T}\rangle$ is a vector of variables representing the proportion of loans portfolio distributed according to the maturity of loans - maturity up to 5 years (UP5Y), and maturity exceeding 5 years $(\boldsymbol{E X 5 Y})$; and $\langle\boldsymbol{C N C}\rangle$ is a vector of variables representing the proportion of loans portfolio distributed in the one hundred largest customers $(\boldsymbol{U P 1 H})$, and to other customers $(\boldsymbol{E X 1 H})$. Significance of parameters: $1 \%(* * *), 5 \%(* *)$, and $10 \%(*)$.

With regard to variables commonly used in previous models, the results confirm the expected positive and significant relationships of $L L P$ with the change in the value of loans, the value of nonperforming loans in the immediately preceding period, the change in the value 
of nonperforming loans, and the value of written-off loans. On the other hand, it was not confirmed the expected positive relationship between the dependent variable and LLA. This outcome suggests that in the Brazilian banking market the cumulative balance of the provision in one period is not a good indicator for the amount of loss provision to be recognized in the subsequent period.

Particularly with respect to variables suggested in this model, the positive and significant relationship of $L L P$ with the implicit interest rate of the loan portfolio is confirmed, endorsing expectations that higher interest rates suggest higher credit risk. Also according to expectations, we found a negative relationship of $L L P$ with the rate of GDP growth, indicating that, in times of greater economic activity there is a reduction in expected losses and, consequently, in the corresponding provision.

With respect to the variables controlling for the effects of the characteristics of the loans portfolio regarding the types of loans, the geographical location of debtors, degree of concentration of loans and the maturity of loans, we found evidence showing the importance of controlling for these factors - vectors $T I P, G E O, M A T$ and $C N C$, respectively.

With respect to the types of loans, the results show that the level of $L L P$ recognized by Brazilian banks in each period is significantly lower for loans granted to the private sector $(P R V)$ as compared to those granted to the public sector $(P U B)$ and to nonresidents, revealing that there is a greater perception of risk in loans granted to public entities.

When it comes to the geographic location of borrowers, the empirical evidence show that banks place less loss provisions to loans granted to clients from the Southeast Region $(S E)$ and from abroad (EXT) as compared to clients from other locations $(O R B)$, meaning that less economically developed regions are regarded as being more risky by bank managers.

When we analyze loan maturity, the results on Table 2 show that the constitution of LLP is significantly smaller for loans with maturity over five years (EX5Y) as compared to those with maturity up to five years (UP5Y). This evidence disagrees with the theoretical principle that the longer the maturity of a loan operation, the higher the risk involved. This can be explained, though, by the characteristics of the Brazilian banking market, where a relevant portion of long-term loans are subsidized by the Government, by means of loans intermediated by the National Bank for Economic and Social Development (BNDES).

Finally, with respect to the degree of concentration of the loan portfolio, we found that the corresponding loss provisions are significantly larger where a higher concentration of 
loans granted to the bank's one hundred largest clients $(U P 1 H)$. These results are consistent with the assumption that a portfolio's credit risk is inversely related with its degree of concentration.

Summing up, the results shown in Table 2 corroborate the consistency of model (3.1), by confirming empirically the theoretical assumptions considered in its specification, and becoming the first step in its validation.

\subsection{MODEL COMPARISON}

In order to validate the effectiveness of the proposed model, we initially evaluate the relative goodness of fit across models by means of their adjusted $\mathrm{R}^{2} \mathrm{~s}$. This comparison is shown in Table 3.

Table 3: Comparison of models by means of the adjusted $\mathbf{R}^{2}$

\begin{tabular}{cccccccc}
\hline Model & Adjusted $\boldsymbol{R}^{2}$ & & Model & Adjusted $\boldsymbol{R}^{2}$ & & Model & Adjusted $\boldsymbol{R}^{2}$ \\
\cline { 1 - 2 } Mod. (3.1) & $\mathbf{0 . 4 7 3 3}$ & & & & & & \\
Mod. A & 0.3779 & & Mod. D & 0.4496 & & Mod. G & 0.4603 \\
Mod. B & 0.4417 & & Mod. E & 0.4704 & & Mod. H & 0.4792 \\
Mod. C & 0.4417 & & Mod. F & 0.4530 & & Mod. I & 0.3779 \\
\hline
\end{tabular}

Models: (A) Beaver and Engel (1996); (B) Kanagaretnam, Lobo and Mathieu (2003); (C) Kanagaretnam, Lobo and Mathieu (2004); (D) Zendersky (2005); (E) Marcondes (2008); (F) Kanagaretnam, Krishnan and Lobo (2009); (G) Kanagaretnam, Krishnan and Lobo (2010); (H) Kanagaretnam, Lim and Lobo (2010); (I) Cheng, Warfield and Ye (2011), listed in Table 1. Model (3.1) is the proposed in the present study.

The comparison of the models' adjusted $R^{2}$ s indicates that, with the exception of models A and I of Beaver and Engel (1996) and Cheng, Warfiels and Ye (2011), respectively, the remaining models present reasonably similar results. It can be seen that the model (3.1) present the second largest adjusted $\mathrm{R}^{2}$ among the ten models assessed, being only surpassed by model $\mathrm{H}$ of Kanagaretnam, Lim and Lobo (2010), even though by a narrow margin: 0.4792 versus 0.4733 .

As in Dechow (1994) and Subramanyam (1996), we performed Vuong's (1989) model selection test for identifying if the model (3.1) is efficient to estimates $L L P$ formation. In this procedure, the model (3.1) is tested against each of the other models under the null hypothesis that the two assessed models are equally appropriate to explain the true data generation process against the alternative hypothesis that one of them is more accurate. The test results, considering a confidence level of $95 \%(z=1.96)$, are synthesized in Table 4. 
Table 4: Vuong's (1989) model selection test (95\% confidence level)

\begin{tabular}{|c|c|c|}
\hline Test & z-vuong & Conclusion \\
\hline Model (3.1) x Model A & -4.9193 & Model (3.1) is more accurate. \\
\hline Model (3.1) x Model B & -3.3130 & Model (3.1) is more accurate. \\
\hline Model (3.1) x Model C & -3.3130 & Model (3.1) is more accurate. \\
\hline Model (3.1) x Model D & -3.4361 & Model (3.1) is more accurate. \\
\hline Model (3.1) x Model E & 1.4489 & Models (3.1) and E are equally suitable. \\
\hline Model (3.1) x Model F & -2.5651 & Model (3.1) is more accurate. \\
\hline Model (3.1) x Model G & 1.3894 & Models (3.1) and G are equally suitable. \\
\hline Model (3.1) x Model H & -0.0534 & Model (3.1) and $\mathrm{H}$ are equally suitable. \\
\hline Model (3.1) x Model I & -4.9193 & Model (3.1) is more accurate. \\
\hline
\end{tabular}

Models: (A) Beaver and Engel (1996); (B) Kanagaretnam, Lobo and Mathieu (2003); (C) Kanagaretnam, Lobo and Mathieu (2004); (D) Zendersky (2005); (E) Marcondes (2008); (F) Kanagaretnam, Krishnan and Lobo (2009); (G) Kanagaretnam, Krishnan and Lobo (2010); (H) Kanagaretnam, Lim and Lobo (2010); (I) Cheng, Warfield and Ye (2011). Model (3.1) is the proposed in the present study.

Vuong's test results show that the model proposed in this study is not surpassed by any of the other models examined. It seems more accurate than six competitors and it is equally suitable when compared to models E, G and H of Marcondes (2008), Kanagaretnam, Krishnan and Lobo (2010) and Kanagaretnam, Lim and Lobo (2010), respectively.

Given the restriction that Vuong's test is not adequate to test nested models and considering that models B, C and D can be regarded as reduced versions of the model (3.1) proposed in this study, we performed an F test for nested models (Greene, 2002) in order to compare them with model (3.1). The results of this test are consolidated in Table 5.

Table 6: $F$-test for comparison of nested models with model (3.1)

\begin{tabular}{|c|c|c|}
\hline Test & $F$-stat & Test Result \\
\hline Model (3.1) x Model B & 78.4384 & $\begin{array}{l}\boldsymbol{H}_{\boldsymbol{O}} \text { is rejected. At least one of the parameters of variables } \\
\text { addded to the reduced model (B) is different from zero. }\end{array}$ \\
\hline Model (3.1) x Model C & 78.4384 & $\begin{array}{l}\boldsymbol{H}_{\boldsymbol{0}} \text { is rejected. At least one of the parameters of variables } \\
\text { addded to the reduced model }(\mathrm{C}) \text { is different from zero. }\end{array}$ \\
\hline Model (3.1) x Model D & 81.6627 & $\begin{array}{l}\boldsymbol{H}_{0} \text { is rejected. At least one of the parameters of variables } \\
\text { addded to the reduced model (B) is different from zero. }\end{array}$ \\
\hline
\end{tabular}

Models: (B) Kanagaretnam, Lobo and Mathieu (2003); (C) Kanagaretnam, Lobo and Mathieu (2004); (D) Zendersky (2005). Model (3.1) is the one proposed in the present study.

As shown, the tests performed involving model (3.1) and the nested models (B, C, and D) point out that the parameters of the additional variables incorporated to the reduced models 
improve the explanatory power of the regression.

Therefore, the comparison of adjusted $R^{2}$ s, Vuong's tests and F-test for nested models confirm the efficiency of model (3.1) in explaining the true data generation process.

\subsection{ANALYSIS OF PERSISTENCE OF THE DISCRETIONARY AND NON- DISCRETIONARY COMPONENTS}

The last stage in the process of validating model (3.1) is analogous to the procedure used by Dechow, Richardson and Tuna (2003), consisting of the analysis of persistence of discretionary and non-discretionary components of $L L P$. The idea behind the test is that the greater persistence of the accruals' non-discretionary component and the greater transience of its discretionary portion is a way of validating the model. The reason for this is that opportunistic actions carried out by the management tend to be transitory in nature, while the non-discretionary portion tends to be more persistent since it is determined by economic factors.

Accordingly, we estimate model (4.6) using the non-discretionary components NDLLP and the discretionary component DLLP (residuals). NDLLP corresponds to the estimation of parameters of the explanatory variables, while DLLP corresponds to the residuals generated by means of the estimation of models (3.1), A, B, C, D, E, G, H and I, respectively. The results are consolidated in Table 6.

Table 6: Persistence of discretionary and non-discretionary components of LLP obtained from different models, p-values in parentheses

\begin{tabular}{|c|c|c|c|c|c|c|}
\hline \multicolumn{7}{|c|}{$L L P_{i, t+1}=\alpha+\beta_{1} N D L L P_{i, t}+\beta_{2} D L L P_{i, t}+\varepsilon_{i, t+1}$} \\
\hline Models & $C$ & $N D L L P$ & $D L L P$ & & & $N D L L P-D L L P$ \\
\hline \multirow[t]{2}{*}{ Mod. (3.1) } & 0.0021 & 0.6636 & 0.1766 & Adjusted $R^{2}$ : & 0.4167 & 0.4870 \\
\hline & $(0.0000)$ & $(0.0000)$ & $(0.0000)$ & F Statistic: & 24.0001 & \\
\hline \multirow[t]{2}{*}{ Mod. A } & 0.0032 & 0.4226 & 0.2755 & Adjusted $R^{2}$ : & 0.3924 & 0.1471 \\
\hline & $(0.0000)$ & $(0.0000)$ & $(0.0000)$ & F Statistic: & 23.6399 & \\
\hline \multirow[t]{2}{*}{ Mod. B } & 0.0018 & 0.6898 & 0.2178 & Adjusted $R^{2}$ : & 0.3487 & 0.4720 \\
\hline & $(0.0000)$ & $(0.0000)$ & $(0.0000)$ & F Statistic: & 19.7058 & \\
\hline \multirow[t]{2}{*}{ Mod. C } & 0.0018 & 0.6898 & 0.2178 & Adjusted $R^{2}$ : & 0.3487 & 0.4720 \\
\hline & $(0.0000)$ & $(0.0000)$ & $(0.0000)$ & F Statistic: & 19.7058 & \\
\hline \multirow[t]{2}{*}{ Mod. D } & 0.0020 & 0.6542 & 0.2168 & Adjusted $R^{2}$ : & 0.3476 & 0.4374 \\
\hline & $(0.0000)$ & $(0.0000)$ & $(0.0000)$ & F Statistic: & 19.5976 & \\
\hline
\end{tabular}




\begin{tabular}{|c|c|c|c|c|c|c|}
\hline \multirow[t]{2}{*}{ Mod. E } & 0.0022 & 0.6502 & 0.1799 & Adjusted $R^{2}$ : & 0.4154 & 0.4703 \\
\hline & $(0.0000)$ & $(0.0000)$ & $(0.0000)$ & F Statistic: & 23.9477 & \\
\hline \multirow[t]{2}{*}{ Mod. F } & 0.0021 & 0.6404 & 0.2141 & Adjusted $R^{2}$ : & 0.3477 & 0.4263 \\
\hline & $(0.0000)$ & $(0.0000)$ & $(0.0000)$ & F Statistic: & 19.6023 & \\
\hline \multirow[t]{2}{*}{ Mod. G } & 0.0022 & 0.6585 & 0.1773 & Adjusted $R^{2}$ : & 0.4160 & 0.4812 \\
\hline & $(0.0000)$ & $(0.0000)$ & $(0.0000)$ & F Statistic: & 23.9811 & \\
\hline \multirow[t]{2}{*}{ Mod. H } & 0.0033 & 0.4015 & 0.0784 & Adjusted $R^{2}$ : & 0.3906 & 0.3231 \\
\hline & $(0.0000)$ & $(0.0000)$ & $(0.0000)$ & F Statistic: & 21.7538 & \\
\hline \multirow[t]{2}{*}{ Mod. I } & 0.0032 & 0.4226 & 0.2755 & Adjusted $R^{2}$ : & 0.3924 & 0.1471 \\
\hline & $(0.0000)$ & $(0.0000)$ & $(0.0000)$ & F Statistic: & 23.6399 & \\
\hline
\end{tabular}

Models: (A) Beaver and Engel (1996); (B) Kanagaretnam, Lobo and Mathieu (2003); (C) Kanagaretnam, Lobo and Mathieu (2004); (D) Zendersky (2005); (E) Marcondes (2008); (F) Kanagaretnam, Krishnan and Lobo (2009); (G) Kanagaretnam, Krishnan and Lobo (2010); (H) Kanagaretnam, Lim and Lobo (2010); (I) Cheng, Warfield and Ye (2011), according to Table 1. The model (3.1) is the proposed in the present study.

In all other models, the estimated coefficients of the discretionary portion are smaller than those of the non-discretionary portion, which is consistent with the assumption that the discretionary portion is more transient (less persistent) than the non-discretionary one. However, the analysis of the estimated coefficients associated to NDLLP and DLLP in each model show that some estimates present a degree of persistence of the non-discretionary portion significantly smaller than others. This is the case of models $\mathrm{A}, \mathrm{H}$, and I, which present estimates around 0.4, while the others are situated around 0.6.

With respect to model (3.1), the estimates show that it presents a degree of persistence of NDPLL higher than seven competing models, with an estimated coefficient lower, although very close to those of models B and C (0.6898 versus 0.6636$)$. By assessing the estimates of coefficients associated to $D L L P$, the empirical tests show that the model of interest is the one that presented the second largest degree of transience (lower degree of persistence), losing only to model $\mathrm{H}$, which by its turn had shown a quite lower degree of NDLLP persistence.

Considering the combination of the two aspects - NDLLP persistence and DLLP transience - model (3.1) is the one presenting the best results. The difference between the estimated coefficients of the two components in the proposed model is 0.4870 . Although the difference between the proposed model and models G, B, C e E can be considered marginal, the main purpose of this study, namely the proposition and validation of model (3.1), is achieved since this is the model showing a very good performance when compared to the other models tested. 
Summing up, the application of the test suggested by Dechow, Richardson and Tuna (2003) strengthens the robustness of the model proposed in this study, adding to the previous procedures of regression parameter analysis with respect to expectations, comparison of adjusted $\mathrm{R}^{2}$ s, Vuong's (1989) tests, and $F$-tests for nested models.

\section{CONCLUSION}

Taking into account guidelines set up by international and Brazilian regulatory agencies on the aspects that must be considered by banks in the constitution of loan loss provisions, the present study aims to assess whether the incorporation of variables representing the current economic situation and the attributes of the loan portfolio, such as the types of loans, the geographical location of debtors, the degree of concentration of the portfolio and the maturities of ongoing loans, improve the specification of models designed to identify the management's discretion on this subject.

The model here proposed includes regressors traditionally found in the literature attempting to explain the level of loan loss provisions - change in loans, the amount of nonperforming loans, the change in the amount of nonperforming loans, net written-off loans, and the loan loss allowance (LLA) in the previous period. Besides, the proposed model also includes variables representing the loan portfolio's implicit interest rate, the level of economic activity, the types of loans, the geographical location of debtors, the degree of concentration of the portfolio and the maturity of loans.

In the first stage of the empirical tests performed, we attest the consistency of the proposed model regarding the expected behavior of the regressors' coefficients and the significance of the control variables. A comparative analysis of the results of the proposed model with those of other two-stage models found in the literature was then carried out. The adjusted $R^{2}$ statistics, which enables comparison of the models' goodness of fit taking into account the loss of degrees of freedom resulting from the incorporation of extra regressors, revealed that the proposed model presents the second-highest statistics among the ten models examined. Vuong's (1989) model selection test was also performed, confirming that the proposed model is not surpassed by any of the other models examined, besides being more accurate than six competing models and equally suitable when compared to the others. The F test for comparison of nested models showed that the additional variables included in our proposed model improve model specification. The assessment of the proposed model is concluded with the analysis of persistence of the discretionary and non-discretionary components of loan loss provisions. The proposed model stands out among those with the 
best performance, by showing a greater degree of persistence of the non-discretionary component and a greater transience of the discretionary component, as expected.

Therefore, the empirical results show that extending the two-stage models traditionally used in the literature for estimating LLP by banks by incorporating variables representing the current economic situation and attributes of the loan portfolio, improves the identification of discretion practiced by the management in this matter.

With respect to the paper's limitations, besides the non-literal replication of the models used for comparison for reasons exposed in section 4.2, the empirical tests are specifically focused on the Brazilian market, which adopts regulations based on expected losses, although they also contemplate some aspects of incurred losses in the guidelines for the establishment of the loan loss provisions. Therefore, the application of the proposed model in a market that adopts the regulatory concept of incurred losses may produce results that are not necessarily equivalent. For this reason, we suggested that future research should test the validity of the proposed model in banking markets where the regulations associated to loan loss provisions are based on the principle of incurred losses.

\section{REFERENCES}

AHMED, A.; TAKEDA, C.; THOMAS, S. Bank loan loss provisions reexamination of capital management, earnings management and signaling effects. Journal of Accounting and

Economics, v. 28, n. 1, p. 1-25, nov. 1999.

ALALI, F.; JAGGI, B. Earnings versus capital ratios management: role of bank types and SFAS 114. Review of Quantitative Finance and Accounting, v. 36, n. 1, p. 105-132, mar. 2010.

\section{BASLE COMMITTEE ON BANKING SUPERVISION (BCBS). Enhancing bank} transparency: public disclosure and supervisory information that promote safety and soundness in banking systems. 1998. Disponível em: 〈http://www.bis.org/publ/bcbs41.pdf $\rangle$. Acesso em: 20 jul. 2013.

BALTAGI, B. H. Econometric analysis of panel data. 4. ed. New Jersey: John Wiley \& Sons, 2008.

BEAVER, W. H.; ENGEL, E. E. Discretionary behavior with respect to allowance for loan losses and the behavior of securities prices. Journal of Accounting and Economics, v. 22, n. 1-3, p. 177-206, ago./dez. 1996.

CHENG, Q.; WARFIELD, T.; YE, M. Equity incentives and earnings management: evidence from the banking industry. Journal of Accounting, Auditing and Finance, v. 26, n. 2, p. 317-349, abr. 2011. 
CONSELHO MONETÁRIO NACIONAL (CMN). Resolução 2.682, de 21 de dezembro de 1999. Dispõe sobre critérios de classificação das operações de crédito e regras para constituição de provisão para créditos de liquidação duvidosa. Diário Oficial [da] República Federativa do Brasil, Banco Central Brasil, Brasília, 21 dez. 1999.

CORNETT, M. M.; McNUTT, J. J.; TEHRANIAN, H. Corporate governance and earnings management at large U.S. bank holding companies. Social Science Research Network, Working Paper Series, 2006. Disponível em: <http://papers.ssrn.com/sol3/papers.cfm?abstract_id=886115>.

DECHOW, P. M. Accounting earnings and cash flows as measures of firm performance: the role of accounting accruals. Journal of Accounting and Economics, v. 18, n. 1-3, p. 3-42, 1994.

DECHOW, P. M.; SLOAN, R.; SWEENEY, A. Detecting earnings management. The Accounting Review, v. 70, n. 2, p. 193-225, abr. 1995.

DECHOW, P. M.; RICHARDSON, S. A.; TUNA, R. Why are earnings kinky? An examination of the earnings management explanation. Review of Accounting Studies, v. 8, n. 2-3, p. 355-384, jun. 2003.

EDILSON, P. Manipulação das informações contábeis: uma análise teórica e empírica sobre os modelos operacionais de detecção de gerenciamento de resultados. ("Manipulation of Accounting Information: A Theoretical and Empirical Analysis of Operating Mop. dels for Detection of Earnings Management"). Unpublished doctoral thesis (Graduate Program in Accounting - University of Sao Paulo/USP). São Paulo, 2007, 260 p.

FEDERAL FINANCIAL INSTITUTIONS EXAMINATION COUNCIL (FFIEC). Policy statement on allowance for loan and lease losses methodologies and documentation for banks and savings institutions, Federal Register, 6 de julho de 2001.

FEDERAL RESERVE BOARD (FED). Joint interagency statement. Federal Reserve Release, 24 nov. 1998. Disponível em: <http://www.federalreserve.gov/boarddocs/press/ general/1998/19981124/default.htm $>$. Acesso em: 17 jan. 2011.

GOULART, A. M. C. Gerenciamento de resultados contábeis em instituições financeiras no Brasil. 2007. 219 f. Tese (Doutorado em Ciências Contábeis) - Departamento de Contabilidade e Atuária da Faculdade de Economia, Administração e Contabilidade, Universidade de São Paulo, 2007.

GRAY, R. P.; CLARKE, F. L. A methodology for calculating the allowance for loan losses in commercial banks. Abacus, v. 40, n. 3, p. 321-341, out. 2004.

GREENE, W. H. Econometric analysis. 5. ed. Upper Saddle River, NJ: Pearson, 2002.

HEALY, P. M.; WAHLEN, J. M. A review of the earnings management literature and its implications for standard setting. Accounting Horizons, v. 13, n. 4, p. 365-384, dez. 1999.

INTERNATIONAL ACCOUNTING STANDARDS BOARD (IASB). IFRS - International Financial Reporting Standards, Ibracon, 2011.

JONES, K. L.; KRISHNAN, G. V.; MELENDREZ, K. D. Do models of discretionary 
accruals detect actual cases of fraudulent and restated earnings? An empirical evaluation. Contemporary Accounting Research, v. 25, n. 2, p. 499-531, 2008.

KANAGARETNAM, K.; LIM, C. Y.; LOBO, G. J. Auditor reputation and earnings management: international evidence from the banking industry. Journal of banking and Finance, v. 34, n. 10, p. 2318-2327, jan. 2010.

KANAGARETNAM, K.; LOBO, G. J.; MATHIEU, R. Earnings management to reduce earnings variability: evidence from bank loan loss provisions. Review of Accounting \& Finance, v. 3, n. 1, p. 128-148, 2004.

KANAGARETNAM, K., LOBO, G. J.; MATHIEU, R. Managerial incentives for income smoothing through bank loan loss provision. Review of Quantitative Finance and Accounting, v. 20, n. 1, p. 63-80, jan. 2003.

KANAGARETNAM, K.; KRISHNAN, G.; LOBO, G. J. An empirical analysis of auditor independence in the banking industry. The Accounting Review, v. 85, n. 6, p. 2011-2046, 2010 .

KANAGARETNAM, K.; KRISHNAN, G.; LOBO, G. J. Is the market valuation of banks' loan loss provision conditional on auditor reputation? Journal of Banking and Finance, v. 33, n. 6, p.1039-1047, jun. 2009.

KIM, M.; KROSS, W. The impact of the 1989 change in bank capital standards on loan loss provision and loan write-offs. Journal of Accounting and Economics, v. 25, n. 1, p. 69-99, fev. 1998.

LOBO, G. J.; YANG, D. H. Bank managers' heterogeneous decisions on discretionary loan loss provisions. Review of Quantitative Finance and Accounting, v. 16, n. 3, p. 223-250, maio 2003.

MARCONDES, D. A. Disciplina de mercado e as acumulações contábeis discricionárias. 2008. 150 f. Tese (Doutorado em Ciências Contábeis) - Departamento de Contabilidade e Atuária da Faculdade de Economia, Administração e Contabilidade, Universidade de São Paulo, 2008.

McNICHOLS, M. Research design issues in earnings management studies. Journal of Accounting and Public Policy, v. 19, n. 4-5, p. 313-345, 2000.

SHRIEVES, R. E.; DAHL, D. Discretionary accounting and the behavior of Japanese banks under financial duress. Journal of Banking and Finance, v. 27, n. 7, p. 1219-1243, jul. 2003.

STEPHANOU, C. Rethinking market discipline in banking: lessons from the financial crisis. Policy Research Working Paper, 5227, The World Bank, mar. 2010. Disponível em: <http://www.iadb.org/intal/intalcdi/PE/2010/04744.pdf >.

SUBRAMANYAM, K. R. The pricing of discretionary accruals. Journal of Accounting and Economics, v. 22, n. 1-3, p. 249-281, ago./dez. 1996.

VUONG, Q. H. Likelihood ratio tests for model selection and non-nested hypotheses.

Econometrica, v. 57, n. 2, p. 307-333, mar. 1989. 
ZENDERSKY, H. C. Gerenciamento de resultados em instituições financeiras no Brasil 2000 a 2004. 2005. 133 f. Dissertação (Mestrado em Ciências Contábeis) - Programa Multiinstitucional e Inter-Regional de Pós-Graduação em Ciências Contábeis, Universidade de Brasília, Universidade Federal da Paraíba, Universidade Federal de Pernambuco, Universidade Federal do Rio Grande do Norte, Brasília, 2005.

\footnotetext{
${ }^{\mathrm{i}}$ The National Monetary Council (CMN in Portuguese language acronym) is the highest-ranking authority in the Brazilian financial system. It is composed by the Finance and Planning Ministers and by the President of the Central Bank. It issues the principal guidelines regarding economic policies to be followed by the regulatory agencies operating in the Brazilian financial system.
} 